\title{
GERMINATION RATES OF OLD AND FRESH SEEDS AND THEIR IMPLICATIONS ON INVASIVENESS OF THE ORNAMENTAL CANARY ISLANDS DATE PALM (PHOENIX CANARIENSIS)
}

\author{
Dirk HR Spennemann ${ }^{1}$, Melissa Pike ${ }^{2} \&$ Wayne Robinson ${ }^{3}$ \\ ${ }^{1}$ Institute for Land, Water and Society; Charles Sturt University; PO Box 789; Albury NSW 2640 \\ dspennemann@csu.edu.au (correspondingauthor) \\ ORCID: 0000-0003-2639-7950 \\ ${ }^{2}$ School of Environmental Sciences, Charles Sturt University; PO Box 789; Albury NSW 2640 \\ mel.pike.10@gmail.com \\ ORCID: 0000-0003-3463-9921 \\ ${ }^{3}$ Institute for Land, Water and Society; Charles Sturt University; PO Box 789; Albury NSW 2640 \\ wrobinson@csu.edu.au \\ ORCID: 0000-0002-8793-7466
}

\begin{abstract}
.
In many countries, Canary Islands Date Palms (Phoenix canariensis Chabaud) have escaped their horticulturally managed settings and have commenced to colonise surrounding natural bushland. While dispersed by various vectors, both birds and canids such as foxes, fluctuating environmental conditions may inhibit germination in the season of deposition. The potential of old, previous season's seeds to germinate when conditions turn favourable has direct implications on the plant's ability to establish viable, colonising populations. Nothing is known about the ability of older, previous season's seeds to successfully germinate.

Based on experimental data, using seeds collected under a range of palms in the Southern Riverina of New South Wales (Australia), this paper shows that the seeds of Phoenix canariensis exhibit low inter-seasonal variations in their germination potential indicating that a seed bank will remain viable for several years. Substantial variability was observed between specimens of the same plantation which is caused by the high genetic diversity inherent in a given palm ornamental population, as well as by a range of environmental factors. At the present stage, it is impossible to separate these two. Directions for further research are outlined.
\end{abstract}

Key words: Palmae; seed germination; invasive species; seed dormancy; seed mass; intraspecific variability

\section{INTRODUCTION}

Canary Islands Date Palms (Phoenix canariensis Chabaud) are ubiquitous ornamental plants that are distributed well beyond their endemic range (see below). As garden escapees, they have become an invasive environmental plant in several countries, including Australia (Di Tomaso \& Healy 2006; Meyer et al. 2008; Staples et al. 2000; Williams 2008; Wotherspoon \& Wotherspoon 2002), even though the exact biomechanical and biochemical processes of dispersal (i.e. during gastrointestinal passage) are not yet well understood (Spennemann 2019c).

Canary Islands Date Palms rely on a range of vectors for their dispersal and the colonisation of new areas. Conceptually we need to consider seeds that derive from abscised drupes falling underneath the canopy of the palm and those that are moved by various vectors (frugivorous animals, surface water flow, etc.) to new locations. Depending on the nature of dispersal, the quantity of seeds ranges from very large without any effective dispersal (e.g. underneath the source palm) (i.e. suisuccession, sensu Spennemann 2020e) to smaller numbers over greater distances (e.g. coyotes and foxes) (Spennemann 2019c, 2020f) (i.e. expansion and colonisation, sensu Spennemann 2020e). Numerous species vectors are on record as dispersing disperse Canary Islands Date Palm seeds (Spennemann 2019c) and often deposit larger quantities of these at the same location, either as scent-marking (e.g. canids) or because the same perch is frequented (e.g. Currawongs \& Spennemann 2018d).

At the point of deposition, a seed's establishment success depends on seed dormancy, soil, temperature, and moisture conditions, as well as the presence of seed predators (e.g. Coccotrypes dac- 
tyliperda, Spennemann 2019a). Once deposited, the seed may encounter conditions that are favourable for immediate germination or may lay dormant for one or more seasons, especially at locations where moisture regimes are marginal (either seasonally or inter-seasonally) and not conducive to immediate germination. Looking at the base of Canary Islands Date Palms planted in low moisture horticultural settings, one notices a plethora of seeds, some that are darkened and stem from the previous year's crop, and some that are light coloured and stem from the current year's crop. Also, there tends to be a number of abscised brown drupes in various stages of desiccation with some flesh adhering (Figure 1). When environmental conditions improve, such a multi-seasonal accumulation of seeds may conceivably lead to an amplified recruitment pulse - if the seeds remain viable.

While some palm species exhibit dormancy (Baskin \& Baskin 2014; Meerow \& Broschat 2017; Odetola 1987), that does not apply to Phoenix canariensis (or its cogener $P$. dactylifera) (Azad et al. 2011; Biradar \& Mahabale 1969). Generally, seeds tend to exhibit a decreasing fitness to germinate as time passes. P. canariensis seed, however, proved to be comparatively tolerant to desiccation, which was also observed in an unrelated study (Batista et al. 2016). Dickie and Pritchard (2002) suggested that tolerance to desiccation may be a residual of the ancestral state of seeds. In the case of $P$. canariensis, tolerance to desiccation is advantageous and enables seed persistence through time in relatively arid or marginal environments (Pammenter \& Berjak 2000). Moderate scarification, for example during the passage through an animal's gastrointestinal system, increases the percentage of germination (Spennemann \& Pike 2019) and it has been posited that exposing a seed (with the pericarp removed) to the environment may enhance its germination potential as well (AlWasel \& Warrag 1998).

Even though Canary Islands Date Palms have become recognised as a potentially invasive plant, nothing is known about the germination potential of older seeds. This study will assess experimentally whether there are inter-annual differences in the germination potential of old vs fresh Phoenix canariensis seeds among individual palms and whether there are differences in the germination percentage and germination rates (speed) of seed between individual palms of the same year.

\section{Materials And Methods Species studied}

The Canary Islands Date Palm (Phoenix canariensis) (Arecaceae) is a dioecious anemophilous plant that is solely propagated by seed (Barrow 1998), with pollination occurring at distances in excess of $390 \mathrm{~m}$ (Saro et al. 2014). Canary Island Date Palms readily and reliably set fruit and seed freely, annually producing between 5,000 and 30,000 obovoid drupes ('dates') (Djouab et al. 2016; Saro et al. 2014), which are a fleshy fruit with a single seed and small amount of fibrous pericarp. The drupes range from $15-30 \mathrm{~mm}$ in length, $12-17 \mathrm{~mm}$ in thickness, and $2-5 \mathrm{~g}$ in mass (Djouab et al. 2016), of which the seed contributes $0.9-1.5 \mathrm{~g}$. The drupes, which occur in hanging clusters, vary widely in their physical properties (shape, length, diameter, mass, colour) between individual palms. When ripe, they tend to attain a dark orange to red colour.

Traditional date palm ( $P$. dactylifera) production distinguishes four distinct stages of ripening of the drupe, from immature green (Arabic: Khimri) and mature, full coloured (Khalal) to soft brown (Rutab) and finally raisin (Tamr) (Ahmed et al. 1995; Baliga et al. 2011). These concepts can be transferred to the congener $P$. canariensis. The fruit attains its maximum weight and size at the end of the Khalal stage. As fruits continue to ripen, the fructose and glucose content tends to rise with increasing daily insolation. At the Rutab stage, the apex starts ripening and the texture of the fruit becomes soft, losing moisture (and thus weight) and the drupe starts turning to a brown or black colour. There is little increase in sugar content between the Rutab and Tamr stage, but the moisture loss is significant (Ahmed et al. 1995; Amira et al. 2011; El Arem et al. 2012; Eltayeb et al. 1999; Martín-Sánchez et al. 2014).

The Canary Island Date Palm reaches reproductive maturity and first flowers after six to seven years, but in some locales between 8 to 10 years (Borzì 1912), which is the first time that a plant's gender can be determined. In the northern (southern) hemisphere Phoenix canariensis drupes ripen between November and February (March and June), with fruit available to birds until late November (pers. obs. DHRS) (Núñez 1997, p. 82). The seed shows its first twoleave shoots at about one year of age.

Unless affected by disease or pests, the plant can live for 200-300 years (Beech 2017). In its native range, $P$. canariensis is endemic to the Canary Islands (Lipnitz \& Kretschmar 1994; Sosa et al. 2016). 
It was quickly and widely dispersed during the second half of the nineteenth century as a horticultural feature plant and street tree (Spennemann 2018a, 2019b; Zona 2008). Today it is distributed globally in all warm temperate regions (Spennemann 2018c).

\section{Germination of Phoenix canariensis}

Compared to the extensive research carried out on its congener, the commercial date palm (Phoenix dactylifera), only a small number of studies have examined aspects of the germination of $P$. canariensis such as desiccation (Batista et al. 2016), salinity resistance (Batista et al. 2016; Djibril et al. 2005; Martfn Alemán et al. 1999), influences of temperature (Chatty \& Tissaoui 1999; Pimenta et al. 2010), scarification (Noto \& Romano 1987; Spennemann \& Pike 2019) as well as pre-soaking of seed (El-Tarawy et al. 1989).

While the emergence of the cotyledonary petiole (often mistakenly called the radicle) (Baskin \& Baskin 2014; Meerow \& Broschat 2017) from the operculum is the most widely accepted method to define successful germination (Chatty \& Tissaoui 1999; Martfn Alemán et al. 1999; Pimenta et al. 2010; Spennemann \& Pike 2019), some authors use the appearance of the first leaf (Batista et al. 2016; Jenhani 1992) or even its unfolding (Pacheco 2001).

Immediately after ripening, the germination rate of $P$. canariensis is very high, with $80 \%$ to $95 \%$ of untreated seeds germinating (Martfn Alemán et al. 1999; Noto \& Romano 1987). Scarification with a weak $\mathrm{H}_{2} \mathrm{SO}_{4}$ solution increased the germination speed of germination by $70 \%$, whereas physical scarification increased the speed by only $38 \%$ (Noto \& Romano 1987, Fig. 2). Scarification in the gastrointestinal tract of vectors can enhance germination rates (Spennemann \& Pike 2019). Numerous studies with seeds of other palm species showed that seed viability decreased with increased dehydration (Batista et al. 2016; Rubio Neto et al. 2012). The same holds true for $P$. canariensis (Batista et al. 2016). Immersion in freshwater hydrated the seeds and sped up germination (El-Tarawy et al. 1989), whereas immersion in saline solutions had delaying and reducing effects (Martfn Alemán et al. 1999).

Stated germination temperatures range from $25^{\circ} \mathrm{C}$ (Chatty \& Tissaoui 1999), $27^{\circ} \mathrm{C}$ (Robinson 2009), or 29-32 ${ }^{\circ} \mathrm{C}$ (Donselman 1982), to $29-35^{\circ} \mathrm{C}$ (Meerow \& Broschat 2017). Pimenta et al. (2010) tested several germination conditions for $P$. canariensis and found that the best germination results were obtained at temperatures fluctuating between $20^{\circ} \mathrm{C}$ (night) and $30^{\circ} \mathrm{C}$ (day), with ranges of $25-35^{\circ} \mathrm{C}$ being second best. Stable temperatures of $30^{\circ} \mathrm{C}$ resulted in comparable germination percentages for Khalal stage drupes (52\% vs 55\%) but in lower percentages for Rutab stage drupes (44\% vs $81 \%$ ). Pimenta et al. (2010) noted that at all tested temperatures the germination rate of Khalal stage drupes was less than that of Rutab drupes, possibly suggesting differences in seed maturity.

\section{Data collection}

The Phoenix canariensis seeds used for the experiment were collected at Alma Park and Albury (New South Wales, Australia). All locations have been previously used for numerous studies on $P$. canariensis (Spennemann 2018d, 2019d; Spennemann \& Pike 2019).

The Alma Park samples comprise a group of 17 palms lining the $200 \mathrm{~m}$ long north-eastern section of a driveway leading to the property 'Glenalvon' (code APL). These are the remnants of a 70- 80-plant alley of palms, planted at the same time in the early to mid-1950s (Spennemann 2020c). Some $2.2 \mathrm{~km}$ to the south-west is Alma Park Church, which shows two groups of four palms each (APC). Each group comprises one larger and three smaller palms, suggesting different planting ages (between the 1940s and 1960s) (Spennemann 2020a). Some $340 \mathrm{~m}$ to the south-east of the church is the 'Netherlands' homestead with two palms (dating to the late 1930s or ear-

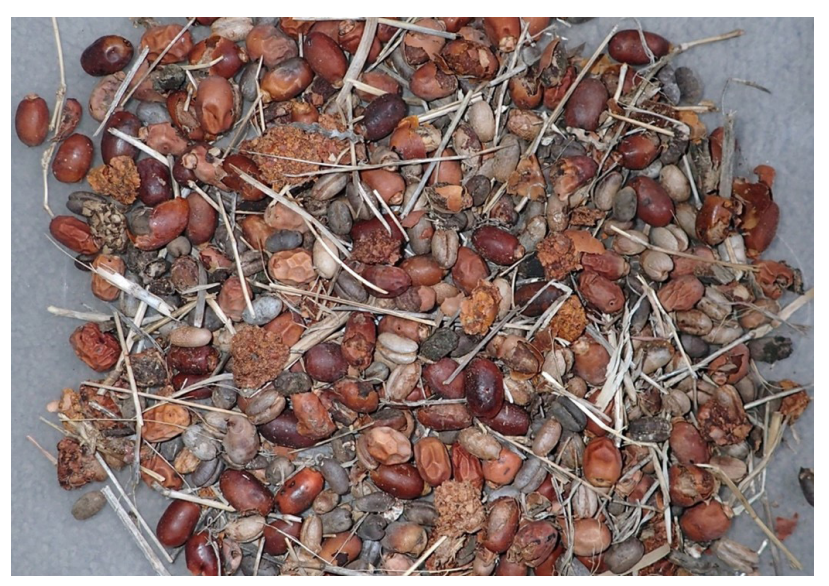

Figure 1. Example of a grab sample (palm APL 5). Note the presence of flying-fox ejecta, brown drupes (Rutab stage), dried up drupes (Tamr stage), light coloured and dark coloured de-fleshed seeds, as well as grass remains. 
ly 1940s) planted at its entrance (APN) (Spennemann 2020b). The Albury sample (ABX) is a 45-year old self-seeded palm in a garden setting at Forrest Hill Avenue. Except for the specimen in Albury, which sits on the boundary between two landscaped, and watered, private gardens, none of the palms were artificially watered since their establishment (for further details see Spennemann 2018d). The samples used for the germination experiments are all grab samples collected under the palms in late May 2018.

\section{Sample preparation}

The Phoenix canariensis seeds and drupes were extracted from the grab samples with the remainder of the sample (flying-fox ejecta, gravel, grass leaves discarded. These seeds and drupes were sorted into three classes: a) drupes of Rutab stage ('brown seeds'); b) drupes of Tamr stage (containing dry light coloured seeds) and de-fleshed light coloured seeds ('light seeds') and c) dark coloured, near black, defleshed seeds ('dark seeds'). The seeds of the two drupe stages were manually extracted by peeling (without the use of a sharp implement). All seeds were inspected for damage, with all incomplete seeds or seeds with rodent gnaw marks (see Spennemann 2018d for examples) discarded. In addition, fresh drupes, both Khalal ('fresh seeds') and Rutab stage ('brown seeds') were collected from the inflorescence of one palm, with all seeds manually extracted by peeling (as per above).

\section{Germination tests}

A plethora of papers comment on the germination of palm seeds in general (Baskin \& Baskin 2014; Broschat \& Donselman 1989; Chatty \& Tissaoui 1999; Donselman 1982; Gátin 1906; Marcus \& Banks 1999; Meerow \& Broschat 2017; Mifsud 1996; Pritchard et al. 2004; Robinson 2009), as well on as the germination on the congener of Phoenix canariensis, the commercially grown date palm Phoenix dactylifera (Azad et al. 2011; Singh \& Bhargava 2009; Sumianah et al. 1984). Only two studies provide data on experimental design related to Phoenix canariensis (El-Tarawy et al. 1989; Pimenta et al. 2010). In addition, there are numerous blogs and websites of palm enthusiasts that recommend a variety of germination techniques, from boxes with seedbed mixtures or wet sand to sealed plastic bags with seeds placed between moist paper tissues.

Pimenta et al. (2010) tested a number of germi- nation conditions for Phoenix canariensis and found that the best germination results were obtained at temperatures fluctuating between $20^{\circ} \mathrm{C}$ (night) and $30^{\circ} \mathrm{C}$ (day), with ranges of $25-35^{\circ} \mathrm{C}$ being second best. Only one study tested the effects of pre-soaking Phoenix canariensis seeds in water (El-Tarawy et al. 1989). He found that soaking seeds in either tap-water for a three-day period increased the germination percentage.

\section{Experimental Design}

The basic methodology used for the experiment followed that of Pimenta et al. (2010), with a regime of 16 hours of simulated daylight and 8 hours of darkness and with environmental temperatures fluctuating between $20^{\circ} \mathrm{C}$ during the 'night' and $30^{\circ} \mathrm{C}$ during the 'day.' The experiment was set up in a climate-controlled, window-less laboratory room of 2.6 x $2.8 \mathrm{~m}$. The light was provided by three AquaOne ${ }^{\circledR}$ EcoGlo90 LED lights, each set up centrally above a plastic container. These lights primarily emit at the 430-490 nm spectrum (blue light) and 420-780nm spectrum (white light, peaks at $460 \mathrm{~nm}$ and 540 $620 \mathrm{~nm}$ ). A stable ambient temperature was achieved by the room-specific air-conditioning system, which could be manually adjusted.

In total, four germination experiments were carried out, a single-seed trial to assess the germination percentages of seeds found in animal scats (trial 1 , design A) (reported in Spennemann \& Pike 2019) and three group trials (trials 2-4, designs B \& C) (principally reported in this paper).

\section{Design A}

The samples were housed in a transparent plastic tub with a lid (34 1; $390 \times 790 \times 155 \mathrm{~mm})$, filled with 13.331 of evenly mixed planting substrate comprised of $50 \%$ peat moss and $50 \%$ Perlite. The surface was levelled and divided into a 3 x 6 grid using wooden skewers. Each cell was populated with nine seeds ( $3 \times 3$ pattern). The seeds had been cleaned of adhering material (if any) and measured prior to the experiment. No fungicides were applied in order to simulate natural conditions. The seeds were pressed into a substrate, level with the surface, and with their operculum pointing upwards. The surface was then moistened with 1.351 of standard tap water sprayed with a pressurised mist sprayer evenly across the surface of the tub. The lids were then replaced for the first $48 \mathrm{hrs}$, after which they were removed. The 
temperature was set at the start of the simulated 'day' to $30^{\circ} \mathrm{C}(17: 00-9: 00)$ and left to cool at the end of the 'day' with the night $(9: 00-17: 00)$ a stable $20^{\circ} \mathrm{C}$. Given the small air space, both the drop and rise of ambient temperature were rapid. Experiment A was carried out between 14 June and 27 July 2018.

\section{Design $B$}

Following numerous advice pages on palm seed, the seeds were placed between moist paper tissues in sealed Ziploc ${ }^{\circledR}$ bags which are then placed in a warm space (Marcus \& Banks 1999; Spanner 2018). One-half of the samples was pre-treated by soaking the seeds in tap water for $24 \mathrm{~h}$, while the other half remained untreated (Table 1). No fungicides were applied to simulate natural conditions. The temperature was set at the start of the simulated 'day' to $30^{\circ} \mathrm{C}$ (17:00-9:00) and let to cool off at the end of the 'day' with the night (9:00-17:00) a stable $20^{\circ} \mathrm{C}$. Given the small air space, both drop and rise of ambient temperature were rapid. Actual room temperatures were logged with a TinyTag Plus 2 TGP-4500 temperature and humidity logger. The bags were opened after two weeks to assess the state of germination. All germinated seeds were removed, the bags remoistened and resealed for another week. This process was repeated twice after which the experiment was terminated. The trial was carried out between 21 June and 20 July 2018.

\section{Design C}

Following the pilot study, the design was adjusted. As the Ziploc ${ }^{\circledR}$ bags proved to be cumbersome to open and close during checking events, they were replaced by $110 \times 165 \times 35 \mathrm{~mm}$ plastic fast-food containers. As before, the seeds were placed between moist paper tissues, and no fungicides were applied. The room temperature was maintained at a stable temperature of $28^{\circ} \mathrm{C}$ as the laboratory space was primarily used for a food preference experiment with Coccotrypes dactyliperda beetles which had emerged from trial \#1 (Spennemann 2018b; Spennemann et al. 2018). The tubs were checked every week for five weeks, with germinated seeds counted and removed. The trials were carried out between 29 August and 3 October 2018 (trial \#3) and between 25 October and 15 November 2018 (trial \#4).

\section{Recording of germination and calculation of germination rates}

In all experiments, the emergence of the cotyledonary petiole from the operculum was taken as successful germination. Three germination ratios were established. The actual germination percentage(AGP) is the percentage of seeds of the total sample (n) that germinated (GS) in a given time frame $(\mathrm{AGP}=\mathrm{GS} * 100 / \mathrm{n})$, whereas the relative germination percentage (RGP) is the percentage of seeds of the total germinated seeds ( $\mathrm{n}[\mathrm{g}]$ ), which germinated $(\mathrm{GS})$ in a given time frame ( $\mathrm{RGP}=\mathrm{GS} * 100 / \mathrm{n}[\mathrm{g}])$. The germination rate (GR) (vide Maguire, 1962) is calculated as the sum of the ratios of seeds that germinated per time interval since the commencement of the experiment (TI) (weeks in this case) $\left(\mathrm{GR}=\sum \mathrm{GS} / \mathrm{TI}\right)$.

\section{Data analysis}

The difference in germination rates between the different types of seed ages (fresh, brown, light, dark) and treatment options (dry, moist, soaked) was tested with a generalised linear mixed-effects model (GLMM) (SAS Institute 2015) using a binomial distribution, with the response variable being the proportion of germinated seeds. In the mixed model, individual palm trees were analysed as random subjects, nested within each random palm group. Pairwise comparisons of the least-squares means of the treatments were made after Scheffe correction for type 1 error (Scheffé 1953).

To further analyse and interpret the variation within each treatment we performed pairwise Chisquared tests comparing germination between individual trees within each of the light and dark treatments and palm groups. In these comparisons, the analysis only draws on $p$-values of $p<0.005$ to moderate the chances of increased type 1 error from performing multiple pairwise tests.

\section{RESULTS}

The data can be examined primarily in terms of inter-seasonal variation using the types of seed ages (fresh, brown, light, dark), as well as in terms of inter-specimen variation, comparing the germination rates of seeds of the same ages collected from neighbouring palms. 


\section{Inter-seasonal variation}

The germination proportions of seeds of ages (fresh, brown, light, dark) are set out in Table 1 and Table 2. The taphonomic conditions of the Glenalvon driveway are homogenous which rules out selective external influences acting on the seeds on the ground. When considering the cumulative actual germination percentage over time (Figure 2), the Alma Park sample shows that the light seeds are delayed in week 1 , but then quickly plateau out, whereas the seeds extracted from the fresh drupe samples tended to have a higher germination rate in week 1, but then exhibit more delayed germination. Light coloured seeds showed the best AGR and dark seeds the worst (Figure 2).

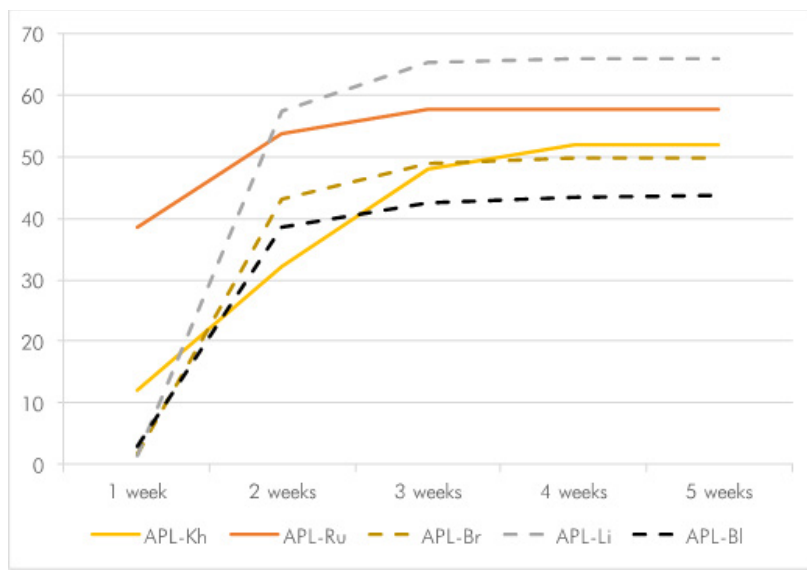

Figure 2. Development of the cumulative actual germination percentage at Glenalvon, Alma Park over time. Aggregate data.

Table 1. Germination trial $\mathrm{n}^{\circ} 2$. Actual germination percentage. Bag method, with and without pre-soaking for 24 hours (in \% of seed germinated). GR - Germination Rate.

\begin{tabular}{|c|c|c|c|c|c|c|c|c|c|c|c|c|c|}
\hline \multirow[b]{2}{*}{ Location } & \multirow[b]{2}{*}{ Sample } & \multicolumn{6}{|c|}{$\begin{array}{l}\text { no soak } \\
\text { weeks (\%) }\end{array}$} & \multicolumn{6}{|c|}{$\begin{array}{l}24 \mathrm{hr} \text { soak } \\
\text { weeks (\%) }\end{array}$} \\
\hline & & 1 & 2 & 3 & 4 & $\mathrm{n}$ & GR & 1 & 2 & 3 & 4 & $\mathrm{n}$ & GR \\
\hline \multirow[t]{5}{*}{ APL 15} & $\begin{array}{l}\text { fresh drupes, } \\
\text { Khalal }\end{array}$ & 0.00 & 92.31 & 92.31 & 92.31 & 39 & 6.59 & 0.00 & 78.38 & 78.38 & 78.38 & 37 & 5.60 \\
\hline & & 0.00 & 71.05 & 71.05 & 71.05 & 38 & 5.08 & 0.00 & 56.76 & 56.76 & 56.76 & 37 & 4.05 \\
\hline & & 0.00 & 35.29 & 44.12 & 47.06 & 34 & 3.05 & 0.00 & 45.45 & 48.48 & 48.48 & 33 & 3.39 \\
\hline & $\begin{array}{l}\text { grab sample, } \\
\text { light }\end{array}$ & 0.00 & 2.94 & 2.94 & 2.94 & 34 & 0.21 & 0.00 & 61.76 & 64.71 & 64.71 & 34 & 4.55 \\
\hline & $\begin{array}{l}\text { grab sample, } \\
\text { dark }\end{array}$ & 0.00 & 12.20 & 12.20 & 12.20 & 41 & 0.87 & 0.00 & 12.50 & 15.00 & 15.00 & 40 & 1.01 \\
\hline \multirow[t]{2}{*}{ Albury } & $\begin{array}{l}\text { grab sample, } \\
\text { light }\end{array}$ & 0.00 & 100.00 & 100.00 & 100.00 & 40 & 7.14 & 0.00 & 97.50 & 97.50 & 97.50 & 40 & 6.96 \\
\hline & $\begin{array}{l}\text { fresh drupes, } \\
\text { Khalal }\end{array}$ & 0.00 & 37.84 & 91.89 & 97.30 & 37 & 5.47 & 0.00 & 21.05 & 86.84 & 89.47 & 38 & 4.73 \\
\hline
\end{tabular}

\begin{tabular}{l|l|l|l|} 
& & & $\begin{array}{l}\text { sample } \\
\text { with better } \\
\text { germination }\end{array}$ \\
\hline Location & Sample & soak $v$ s no soak & no soak \\
& fresh drupes, Khalal & $x 2=2.937 ; p=0.0865$ & no soak \\
& fresh drupes, Rutab & $x 2=1.663 ; p=0.1973$ & soak \\
& grab sample, Rutab & $x 2=0.013 ; p=0.9081$ & soak \\
& grab sample, light & $x 2=27.440 ; p=<0.0001$ & soak \\
& grab sample, dark & $x 2=0.134 ; p=0.7148$ & no soak \\
\hline Albury & grab sample, light & $x 2=0.887 ; p=0.3464$ & no soak \\
& fresh drupes, Khalal & $x 2=1.822 ; p=0.1770$ & \\
\hline
\end{tabular}


Dirk Spennemann et AL. - InVASIVENesS OF PhoENIX CANARIENSIS

Table 2. Germination trials 3 and 4. Actual germination percentage. Plastic tub method (in \% of seed germinated). GR - Germination Rate.

\begin{tabular}{|c|c|c|c|c|c|c|c|c|c|c|c|c|c|c|}
\hline \multirow[b]{2}{*}{ Palm } & \multicolumn{7}{|c|}{$\begin{array}{l}\text { Light Seeds } \\
\text { weeks }(\%)\end{array}$} & \multicolumn{7}{|c|}{$\begin{array}{l}\text { Dark Seeds } \\
\text { weeks }(\%)\end{array}$} \\
\hline & 1 & 2 & 3 & 4 & 5 & $\mathrm{n}$ & GR & 1 & 2 & 3 & 4 & 5 & $\mathrm{n}$ & GR \\
\hline APL1 & 0.0 & 21.7 & 36.7 & 38.3 & 38.3 & 60 & 2.32 & 1.7 & 23.3 & 23.3 & 23.3 & 24.2 & 120 & 1.81 \\
\hline APL3 & 0.0 & 25.7 & 29.7 & 33.7 & 33.7 & 101 & 2.17 & - & 一 & - & - & - & - & - \\
\hline APL5 & 0.0 & 67.5 & 70.0 & 70.0 & 70.0 & 40 & 4.94 & 0.0 & 21.7 & 26.7 & 26.7 & 26.7 & 60 & 1.79 \\
\hline APL7 & 0.0 & 67.5 & 70.0 & 70.0 & 70.0 & 40 & 4.94 & 5.0 & 51.3 & 58.8 & 60.0 & 60.0 & 80 & 4.42 \\
\hline APL8 & 0.0 & 75.0 & 80.6 & 80.6 & 80.6 & 36 & 5.62 & 0.0 & 46.0 & 55.0 & 57.0 & 58.0 & 100 & 3.81 \\
\hline APL9 & 0.0 & 69.5 & 82.1 & 84.2 & 84.2 & 95 & 5.64 & 0.0 & 55.0 & 58.8 & 60.0 & 60.0 & 80 & 4.15 \\
\hline APL12 & 0.0 & 68.0 & 68.0 & 68.0 & 68.0 & 50 & 4.86 & 8.3 & 70.0 & 70.8 & 70.8 & 70.8 & 120 & 5.63 \\
\hline APL13 & 0.0 & 41.9 & 51.6 & 51.6 & 54.8 & 31 & 3.55 & 1.0 & 20.0 & 25.0 & 25.0 & 25.0 & 100 & 1.74 \\
\hline APL15a *) & 0.0 & 2.9 & 2.9 & 2.9 & & 34 & 0.12 & 0.0 & 12.2 & 12.2 & 12.2 & & 41 & 0.52 \\
\hline APL15b & 35.0 & 50.0 & 50.0 & 50.0 & 50.0 & 20 & 6.07 & - & - & - & - & - & - & - \\
\hline APL17 & 0.0 & 65.0 & 72.0 & 72.0 & 72.0 & 100 & 4.98 & 0.0 & 15.0 & 20.0 & 20.0 & 20.0 & 20 & 1.31 \\
\hline APC1 & 0.0 & 23.3 & 48.3 & 48.3 & 48.3 & 60 & 2.85 & 0.0 & 2.6 & 44.0 & 59.5 & 59.5 & 116 & 2.71 \\
\hline APC2 & 0.0 & 68.3 & 75.0 & 76.7 & 76.7 & 60 & 5.26 & 0.0 & 25.3 & 85.3 & 90.0 & 90.0 & 150 & 4.83 \\
\hline APC3 & 0.0 & 46.7 & 56.7 & 56.7 & 56.7 & 30 & 3.81 & 0.0 & 10.7 & 64.7 & 69.3 & 69.3 & 150 & 3.50 \\
\hline APC5 & 0.0 & 37.5 & 55.8 & 60.0 & 60.0 & 120 & 3.70 & 0.0 & 1.7 & 53.3 & 78.3 & 78.3 & 60 & 3.47 \\
\hline APC6 & 0.0 & 54.2 & 66.7 & 68.3 & 68.3 & 120 & 4.52 & 0.0 & 11.7 & 51.7 & 56.7 & 56.7 & 60 & 2.92 \\
\hline APC 8 & - & - & - & - & - & - & - & 0.0 & 5.3 & 48.7 & 56.7 & 56.7 & 150 & 2.73 \\
\hline APNN & 0.0 & 15.0 & 15.0 & 45.0 & 45.0 & 60 & 2.14 & 0.0 & 12.2 & 54.4 & 63.3 & 63.3 & 90 & 3.20 \\
\hline APNS & 0.0 & 0.8 & 0.8 & 0.8 & 0.8 & 120 & 0.06 & 0.0 & 35.0 & 88.3 & 88.3 & 88.3 & 60 & 5.04 \\
\hline WW1 & 0.0 & 14.3 & 45.7 & 51.4 & 51.4 & 35 & 2.72 & - & - & - & - & - & - & - \\
\hline WW2 & 0.0 & 3.5 & 52.6 & 54.4 & 54.4 & 57 & 2.65 & - & - & - & - & - & - & - \\
\hline WW7 & 0.0 & 20.0 & 83.3 & 83.3 & 83.3 & 30 & 4.44 & 0.0 & 50.0 & 86.4 & 86.4 & 86.4 & 22 & 5.30 \\
\hline WW8 & 0.0 & 0.0 & 41.7 & 55.0 & 55.0 & 60 & 2.46 & 0.0 & 30.0 & 73.3 & 73.3 & 73.3 & 60 & 4.20 \\
\hline WW9 & 0.0 & 0.0 & 27.1 & 32.9 & 32.9 & 70 & 1.50 & 0.0 & 16.9 & 81.4 & 81.4 & 81.4 & 59 & 4.28 \\
\hline
\end{tabular}

\begin{tabular}{l|lllllll}
\hline & \multicolumn{7}{|c}{ Seeds from Brown Drupes } \\
weeks $(\%)$ & & & \\
Palm & 1 & 2 & 3 & 4 & 5 & n & GR \\
\hline APL1 & 0.0 & 50.0 & 66.7 & 66.7 & 66.7 & 12 & 4.37 \\
APL3 & 0.0 & 72.7 & 81.8 & 81.8 & 81.8 & 22 & 5.63 \\
APL5 & 0.0 & 31.0 & 32.0 & 33.0 & 33.0 & 100 & 2.30 \\
APL7 & 0.0 & 45.7 & 54.3 & 56.4 & 56.4 & 94 & 3.75 \\
APL8 & 0.0 & 64.9 & 70.3 & 70.3 & 70.3 & 37 & 4.89 \\
APL9 & 4.0 & 80.0 & 84.0 & 86.0 & 86.0 & 50 & 6.26 \\
APL12 & - & - & - & - & - & - & - \\
APL13 & 0.0 & 15.0 & 20.0 & 21.7 & 21.7 & 60 & 1.37 \\
APL15a & 0.0 & 35.3 & 44.1 & 47.1 & & 34 & 1.70 \\
APL15b & 5.0 & 20.0 & 22.5 & 22.5 & 22.5 & 40 & 1.90 \\
APL17 & 3.1 & 50.0 & 58.2 & 58.2 & 58.2 & 98 & 4.18 \\
\hline APC1 & - & - & - & - & - & & - \\
APC2 & 0.0 & 15.0 & 35.0 & 53.3 & 53.3 & 60 & 2.68 \\
APC3 & 0.0 & 0.0 & 0.0 & 21.7 & 21.7 & 46 & 0.78 \\
APC5 & 0.0 & 0.0 & 50.0 & 50.0 & 50.0 & 8 & 2.38 \\
APC6 & - & - & - & - & - & - & - \\
APC8 & 12.0 & 67.3 & 90.0 & 90.0 & 90.0 & 150 & 6.75 \\
\hline APNN & - & - & - & - & - & - & - \\
APNS & - & - & - & - & - & - & - \\
\hline WW1 & 10.0 & 30.0 & 31.4 & 32.9 & 32.9 & 70 & 2.98 \\
WW2 & 10.0 & 45.0 & 45.0 & 45.0 & 45.0 & 40 & 3.93 \\
WW7 & - & - & - & - & - & - & - \\
WW8 & - & - & - & - & - & - & - \\
WW9 & - & - & - & - & - & - & - \\
\hline
\end{tabular}

*) Sample L15a is reproduced from Table 1. 
Table 3. Significant differences in treatment*seed type combinations. GR-germination rate.

\begin{tabular}{|c|c|c|c|c|c|c|}
\hline Treatment & $\begin{array}{l}\text { Sample A } \\
\text { Seed Type }\end{array}$ & GR (\%) & Treatment & $\begin{array}{l}\text { Sample B } \\
\text { Seed Type }\end{array}$ & GR (\%) & $\begin{array}{l}\text { Adjusted } \\
\qquad p\end{array}$ \\
\hline dry & light & 7.07 & dry & brown & 84.64 & 0.0190 \\
\hline dry & light & 7.07 & soaked & fresh Khalal & 88.97 & 0.0167 \\
\hline dry & dark & 20.54 & dry & brown & 84.64 & 0.0022 \\
\hline dry & dark & 20.54 & dry & fresh Rutab & 76.43 & 0.0165 \\
\hline dry & dark & 20.54 & soaked & light & 52.37 & 0.0328 \\
\hline dry & dark & 20.54 & soaked & fresh Khalal & 88.97 & 0.0052 \\
\hline soaked & dark & 28.20 & dry & brown & 84.64 & 0.0425 \\
\hline soaked & dark & 28.20 & soaked & fresh Khalal & 88.97 & 0.0491 \\
\hline
\end{tabular}

Testing for fixed effects with the GLMM showed that the differences in treatment $(\mathrm{df}=2, \mathrm{~F}=5.96, p=$ 0.007), seed type $(\mathrm{df}=4, \mathrm{~F}=14.01, p<0.0001)$ and treatment*seed type $(\mathrm{df}=6, \mathrm{~F}=13.51, p<0.0001)$ are all significant. Pairwise testing of treatment*seed type combinations after Scheffe correction for type 1 errors showed no significant differences in the vast majority of pairwise comparisons ( 70 out of 78 pairs). Moreover, the germination rates of 37 of a total of 78 sets of pairwise comparison did not differ statistically at $p<0.05$, Differences were only observed among 8 pairs (Table 3).

In these eight instances, dry seeds, in particular the older dark seeds, are less likely to germinate than recent (brown) and fresh seeds, as well as seeds that have been soaked for $24 \mathrm{hrs}$.

\section{Inter-specimen variation}

Environmental conditions, in particular, moisture and sun hours, will influence fruit-setting and subsequent development and ripening of drupes (Aljuburi et al. 2000; Cohen et al. 2014). All samples at Alma Park are within $2.5 \mathrm{~km}$ of each other. At that scale, there are no topographic variables in the undulating landscape that would cause meaningful differences in temperature, precipitation, humidity, or sun hours. The only micro-topographic variation that may have a bearing exists at Glenalvon, with a low $\left(3 \%, 1.72^{\circ}\right)$ slope down the driveway.

As Phoenix canariensis are dioecious and solely propagated from seed, all inter-specimen variation is caused by differences in the male and female plant stock. For each location (except APC) we can be confident that all palms have been sourced from the same nursery and planted out at the same time. They do not form a homogenous gene pool, however, as the horticultural ancestry of the Canary Islands date palms in Australia is complex (Spennemann 2018a, 2019b), leading to extensive variability (Figure 3 ). In the case of the linear array at Glenalvon, all palms were cer- tainly provided by the same supplier; were planted out at the same time in the early to mid-1950s, and were exposed to the same watering and nutrient regime for the past 70 years. Yet there is an unexplained gender difference in sizes, with male palms $(6.5 \pm 3.7$ $\mathrm{m}, \mathrm{n}=6)$ being significantly smaller $(p<0.030)$ than female palms $(7.7 \pm 4.7, n=11)$ (for further details see Spennemann 2018d).

The majority of the individual samples germinated after two weeks, with subsequent smaller increases (Table 2). When considering individual plants, considerable variation in the actual germination percentage can be noted. Table 2 shows that the germination percentage among fresh seeds ranges from $84.2 \%$ (APL9) to $33.7 \%$ (APL3), whereas it ranges from $89.8 \%$ (APL3) to $21.7 \%$ (APL13) among seeds that were extracted from abscised brown drupes.

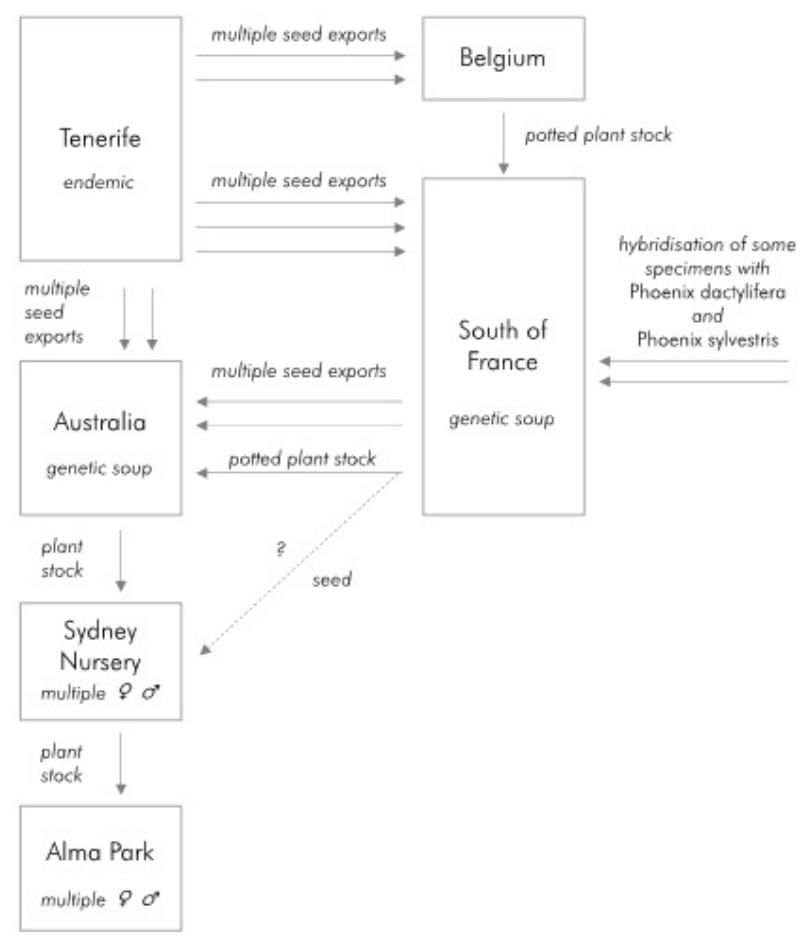

Figure 3. Genealogy of the palms at Alma Park. 
Table 4. Dimensions (in $\mathrm{mm}$ ) and weights (in $\mathrm{g}$ ) of Phoenix canariensis seeds at Glenalvon

\begin{tabular}{|c|c|c|c|c|c|c|}
\hline Sample & Palm & Length (mm) & Width (mm) & Thickness (mm) & Mass (g) & $\mathrm{n}$ \\
\hline Khalal & 15 & $\begin{array}{l}17.87 \pm 1.08 \\
(8.60-19.30)\end{array}$ & $\begin{array}{l}10.65 \pm 1.01 \\
(10.27-11.93)\end{array}$ & $\begin{array}{l}9.74 \pm 0.33 \\
(8.44-11.01)\end{array}$ & $\begin{array}{l}1.32 \pm 0.15 \\
(0.7-1.6)\end{array}$ & 101 \\
\hline \multirow[t]{4}{*}{ Rutab } & 15 & $\begin{array}{l}16.33 \pm 1.44 \\
(10.05-18.87)\end{array}$ & $9.88 \pm 0.48(8.93-11.2)$ & $\begin{array}{l}9.09 \pm 0.38 \\
(8.28-9.99)\end{array}$ & $\begin{array}{l}1.05 \pm 0.19 \\
(0.5-1.4)\end{array}$ & 99 \\
\hline & 1 & $\begin{array}{l}14.43 \pm 1.37 \\
(12.02-16.38)\end{array}$ & $8.77 \pm 0.89(6.68-9.76)$ & $\begin{array}{l}8.00 \pm 0.84 \\
(6.20-9.08)\end{array}$ & $\begin{array}{l}0.77 \pm 0.23 \\
(0.4-1.1)\end{array}$ & 15 \\
\hline & 3 & $\begin{array}{l}14.94 \pm 1.17 \\
(13.17-17.67)\end{array}$ & $7.97 \pm 1.21(6.44-9.85)$ & $\begin{array}{l}7.14 \pm 1.07 \\
(5.80-8.91)\end{array}$ & $\begin{array}{l}0.67 \pm 0.26 \\
(0.4-1.2)\end{array}$ & 22 \\
\hline & 5 & $\begin{array}{l}14.06 \pm 1.15 \\
(10.12-17.15)\end{array}$ & $\begin{array}{l}8.29 \pm 0.84 \\
(6.67-10.56)\end{array}$ & $\begin{array}{l}7.43 \pm 0.7 \\
(6.21-8.88)\end{array}$ & $\begin{array}{l}0.67 \pm 0.19 \\
(0.3-1.1)\end{array}$ & 100 \\
\hline \multirow{9}{*}{$\begin{array}{l}\text { Brown } \\
\text { drupes, } \\
\text { abscised, } \\
\text { in grab } \\
\text { sample }\end{array}$} & 7 & $\begin{array}{l}15.34 \pm 0.8 \\
(13.57-17.14)\end{array}$ & $\begin{array}{l}8.16 \pm 0.85 \\
(6.68-10.10)\end{array}$ & $\begin{array}{l}7.57 \pm 0.77 \\
(5.96-9.08)\end{array}$ & $\begin{array}{l}0.75 \pm 0.20 \\
(0.3-1.3)\end{array}$ & 94 \\
\hline & 8 & $\begin{array}{l}14.98 \pm 1.23 \\
(11.18-16.50)\end{array}$ & $8.56 \pm 0.68(7.31-9.79)$ & $\begin{array}{l}7.72 \pm 0.71 \\
(6.45-8.97)\end{array}$ & $\begin{array}{l}0.78 \pm 0.17 \\
(0.4-1.1)\end{array}$ & 37 \\
\hline & 9 & $\begin{array}{l}14.88 \pm 1.02 \\
(11.28-16.76)\end{array}$ & $8.50 \pm 0.74(6.9-10.08)$ & $\begin{array}{l}7.69 \pm 0.67 \\
(5.62-8.91)\end{array}$ & $\begin{array}{l}0.77 \pm 0.18 \\
(0.3-1.1)\end{array}$ & 50 \\
\hline & 13 & $\begin{array}{l}15.66 \pm 1.07 \\
(10.95-17.53)\end{array}$ & $\begin{array}{l}8.72 \pm 0.86 \\
(6.89-10.34)\end{array}$ & $\begin{array}{l}8.08 \pm 0.81 \\
(6.31-9.57)\end{array}$ & $\begin{array}{l}0.85 \pm 0.23 \\
(0.3-1.3)\end{array}$ & 62 \\
\hline & 15 & $\begin{array}{l}16.27 \pm 1.03 \\
(13.58-18.51)\end{array}$ & $\begin{array}{l}8.65 \pm 0.87 \\
(6.12-10.31)\end{array}$ & $\begin{array}{l}7.99 \pm 1.11 \\
(0.91-9.64)\end{array}$ & $\begin{array}{l}0.83 \pm 0.22 \\
(0.3-1.3)\end{array}$ & 92 \\
\hline & 17 & $\begin{array}{l}13.30 \pm 0.66 \\
(11.11-14.62)\end{array}$ & $8.16 \pm 0.51(5.96-9.47)$ & $\begin{array}{l}7.30 \pm 0.53 \\
(4.70-8.45)\end{array}$ & $\begin{array}{l}0.58 \pm 0.13 \\
(0.0-0.8)\end{array}$ & 100 \\
\hline & 1 & $\begin{array}{l}14.88 \pm 0.8 \\
(12.79-16.89)\end{array}$ & $\begin{array}{l}8.92 \pm 0.55 \\
(7.65-10.16)\end{array}$ & $\begin{array}{l}8.23 \pm 0.61 \\
(6.90-9.33)\end{array}$ & $\begin{array}{l}0.89 \pm 0.16 \\
(0.5-1.3)\end{array}$ & 59 \\
\hline & 5 & $\begin{array}{l}14.72 \pm 0.73 \\
(13.52-16.42)\end{array}$ & $\begin{array}{l}9.13 \pm 0.46 \\
(8.25-10.25)\end{array}$ & $\begin{array}{l}8.23 \pm 0.47 \\
(7.38-9.29)\end{array}$ & $\begin{array}{l}0.87 \pm 0.13 \\
(0.7-1.2)\end{array}$ & 41 \\
\hline & 7 & $\begin{array}{l}15.05 \pm 0.77 \\
(13.48-16.70)\end{array}$ & $7.96 \pm 0.80(6.75-9.69)$ & $\begin{array}{l}7.39 \pm 0.72 \\
(6.19-9.01)\end{array}$ & $\begin{array}{l}0.71 \pm 0.17 \\
(0.4-1.0)\end{array}$ & 34 \\
\hline \multirow{9}{*}{$\begin{array}{l}\text { Clean, } \\
\text { light } \\
\text { coloured } \\
\text { seeds, } \\
\text { in grab } \\
\text { sample }\end{array}$} & 8 & $\begin{array}{l}15.59 \pm 0.64 \\
(13.99-16.56)\end{array}$ & $8.86 \pm 0.51(7.45-9.82)$ & $\begin{array}{l}7.99 \pm 0.64 \\
(6.62-9.09)\end{array}$ & $\begin{array}{l}0.86 \pm 0.12 \\
(0.6-1.1)\end{array}$ & 36 \\
\hline & 9 & $\begin{array}{l}15.18 \pm 0.58 \\
(13.33-16.51)\end{array}$ & $\begin{array}{l}9.48 \pm 0.57 \\
(7.57-10.52)\end{array}$ & $\begin{array}{l}8.57 \pm 0.51 \\
(6.89-9.48)\end{array}$ & $\begin{array}{l}0.93 \pm 0.12 \\
(0.6-1.2)\end{array}$ & 95 \\
\hline & 12 & $\begin{array}{l}15.43 \pm 1.44 \\
(9.38-17.87)\end{array}$ & $\begin{array}{l}7.81 \pm 0.76 \\
(6.59-10.52)\end{array}$ & $\begin{array}{l}7.11 \pm 0.78 \\
(5.69-9.62)\end{array}$ & $\begin{array}{l}0.67 \pm 0.20 \\
(0.3-1.3)\end{array}$ & 50 \\
\hline & 13 & $\begin{array}{l}16.03 \pm 1.12 \\
(13.92-17.68)\end{array}$ & $\begin{array}{l}8.89 \pm 0.86 \\
(7.29-10.25)\end{array}$ & $\begin{array}{l}8.23 \pm 0.81 \\
(6.70-9.52)\end{array}$ & $\begin{array}{l}0.92 \pm 0.25 \\
(0.4-1.3)\end{array}$ & 31 \\
\hline & 15 & $\begin{array}{l}16.17 \pm 0.82 \\
(13.77-17.70)\end{array}$ & $\begin{array}{l}8.59 \pm 0.97 \\
(6.75-10.42)\end{array}$ & $\begin{array}{l}8.12 \pm 0.93 \\
(6.21-9.83)\end{array}$ & $\begin{array}{l}0.82 \pm 0.21 \\
(0.4-1.3)\end{array}$ & 93 \\
\hline & 17 & $\begin{array}{l}13.75 \pm 0.81 \\
(11.77-16.22)\end{array}$ & $\begin{array}{l}8.43 \pm 0.62 \\
(7.14-10.32)\end{array}$ & $\begin{array}{l}7.55 \pm 0.67 \\
(6.07-9.57)\end{array}$ & $\begin{array}{l}0.66 \pm 0.18 \\
(0.2-1.3)\end{array}$ & 100 \\
\hline & 1 & $\begin{array}{l}14.24 \pm 0.79 \\
(12.51-16.36)\end{array}$ & $\begin{array}{l}9.02 \pm 0.52 \\
(7.20-10.20)\end{array}$ & $\begin{array}{l}8.07 \pm 0.50 \\
(6.45-9.02)\end{array}$ & $\begin{array}{l}0.70 \pm 0.15 \\
(0.3-1.0)\end{array}$ & 100 \\
\hline & 3 & $\begin{array}{l}14.19 \pm 0.76 \\
(10.90-15.74)\end{array}$ & $8.83 \pm 0.43(6.75-9.74)$ & $\begin{array}{l}8.00 \pm 0.47 \\
(5.87-8.80)\end{array}$ & $\begin{array}{l}0.75 \pm 0.13 \\
(0.3-1.0)\end{array}$ & 100 \\
\hline & 5 & $\begin{array}{l}13.75 \pm 1.04 \\
(11.55-15.82)\end{array}$ & $\begin{array}{l}8.55 \pm 0.61 \\
(6.86-10.08)\end{array}$ & $\begin{array}{l}7.77 \pm 0.61 \\
(5.87-8.96)\end{array}$ & $\begin{array}{l}0.68 \pm 0.15 \\
(0.4-1.0)\end{array}$ & 75 \\
\hline \multirow{7}{*}{$\begin{array}{l}\text { Clean, } \\
\text { dark } \\
\text { coloured } \\
\text { seeds, } \\
\text { in grab } \\
\text { sample }\end{array}$} & 7 & $\begin{array}{l}14.77 \pm 0.70 \\
(13.24-16.52)\end{array}$ & $8.83 \pm 0.42(7.41-9.61)$ & $\begin{array}{l}8.28 \pm 0.44 \\
(6.69-9.04)\end{array}$ & $\begin{array}{l}0.85 \pm 0.13 \\
(0.6-1.1)\end{array}$ & 82 \\
\hline & 8 & $\begin{array}{l}15.37 \pm 0.73 \\
(13.61-17.29)\end{array}$ & $\begin{array}{l}9.08 \pm 0.42 \\
(7.25-10.02)\end{array}$ & $\begin{array}{l}8.46 \pm 0.48 \\
(6.58-9.35)\end{array}$ & $\begin{array}{l}0.89 \pm 0.17 \\
(0.4-1.2)\end{array}$ & 100 \\
\hline & 9 & $\begin{array}{l}14.06 \pm 1.00 \\
(11.59-16.18)\end{array}$ & $8.72 \pm 0.54(7.47-9.96)$ & $\begin{array}{l}7.98 \pm 0.58 \\
(6.35-9.39)\end{array}$ & $\begin{array}{l}0.72 \pm 0.17 \\
(0.4-1.1)\end{array}$ & 81 \\
\hline & 12 & $\begin{array}{l}15.17 \pm 0.92 \\
(12.31-18.24)\end{array}$ & $8.82 \pm 0.53(6.72-9.77)$ & $\begin{array}{l}8.17 \pm 0.59 \\
(6.22-9.29)\end{array}$ & $\begin{array}{l}0.83 \pm 0.17 \\
(0.3-1.2)\end{array}$ & 100 \\
\hline & 13 & $\begin{array}{l}14.80 \pm 0.72 \\
(13.00-17.04)\end{array}$ & $8.75 \pm 0.46(7.14-9.75)$ & $\begin{array}{l}8.18 \pm 0.49 \\
(6.56-9.17)\end{array}$ & $\begin{array}{l}0.79 \pm 0.13 \\
(0.5-1.0)\end{array}$ & 100 \\
\hline & 15 & $\begin{array}{l}14.27 \pm 1.53 \\
(14.64-16.67)\end{array}$ & $8.8 \mathrm{o} \pm 0.43(7.05-9.66)$ & $\begin{array}{l}8.26 \pm 0.42 \\
(6.51-9.00)\end{array}$ & $\begin{array}{l}0.73 \pm 0.14 \\
(0.3-1.0)\end{array}$ & 106 \\
\hline & 17 & $\begin{array}{l}14.17 \pm 0.84 \\
(11.76-15.70)\end{array}$ & $8.89 \pm 0.52(7.64-9.66)$ & $\begin{array}{l}7.99 \pm 0.52 \\
(6.53-8.75)\end{array}$ & $\begin{array}{l}0.64 \pm 0.21 \\
(0.3-0.9)\end{array}$ & 31 \\
\hline
\end{tabular}


Table 5. Results of pair-wise chi-square test for comparing germination percentage between seeds of different palms at the Glenalvon driveway: light seeds, Significance: ${ }^{*} \mathrm{p}<0.05,{ }^{* *} \mathrm{p}<0.005,{ }^{* * *} \mathrm{p}<0.001$

\begin{tabular}{|c|c|c|c|c|c|c|c|c|c|c|c|}
\hline Palm & 1 & 3 & 5 & 7 & 8 & 9 & 12 & 13 & 14 & 15 & 17 \\
\hline 1 & - & 0.6989 & 0.0011 & 0.0011 & 0.0000 & 0.0000 & 0.0011 & 0.1706 & 0.2918 & 0.0001 & 0.0000 \\
\hline 3 & & - & 0.0001 & 0.0001 & 0.0000 & 0.0000 & 0.0001 & 0.0715 & 0.1653 & 0.0001 & 0.0000 \\
\hline 5 & $* *$ & $* * *$ & - & 1.0000 & 0.2886 & 0.0851 & 0.8386 & 0.1135 & 0.1297 & 0.0000 & 0.8129 \\
\hline 7 & $* *$ & $* * *$ & & - & 0.2886 & 0.0851 & 0.8386 & 0.1135 & 0.1297 & 0.0000 & 0.8129 \\
\hline 8 & $* * *$ & $* * *$ & & & - & 0.7267 & 0.1944 & 0.0119 & 0.0172 & 0.0000 & 0.3140 \\
\hline 9 & $* * *$ & $* * *$ & & & & - & 0.0364 & 0.0004 & 0.0013 & 0.0000 & 0.0624 \\
\hline 12 & $* *$ & $* * *$ & & & & $*$ & - & 0.1403 & 0.1591 & 0.0000 & 0.6120 \\
\hline 13 & & & & & $*$ & $* * *$ & & - & 0.9104 & 0.0000 & 0.0347 \\
\hline 14 & & & & & $*$ & $* *$ & & & - & 0.0000 & 0.0535 \\
\hline 15 & $* * *$ & $* * *$ & $* * *$ & $* * *$ & $* * *$ & $* * *$ & $* * *$ & $* * *$ & $* * *$ & - & 0.0000 \\
\hline 17 & $* * *$ & $* * *$ & & & & & & $*$ & & $* * *$ & - \\
\hline
\end{tabular}

Table 6. Results of the pair-wise chi-square test for comparing germination percentage between seeds of different palms at the Glenalvon driveway: dark seeds, Significance: * $\mathrm{p}<0.05, * * \mathrm{p}<0.005, * * * \mathrm{p}<0.001$

\begin{tabular}{|c|c|c|c|c|c|c|c|c|c|}
\hline Palm & 1 & 5 & 7 & 8 & 9 & 12 & 13 & 15 & 17 \\
\hline 1 & - & 0.7150 & 0.0000 & 0.0000 & 0.0000 & 0.0000 & 0.8863 & 0.1049 & 0.7935 \\
\hline 5 & & - & 0.0001 & 0.0001 & 0.0001 & 0.0000 & 0.8152 & 0.0784 & 0.6016 \\
\hline 7 & $* * *$ & $* * *$ & - & 0.7864 & 1.0000 & 0.1436 & 0.0000 & 0.0000 & 0.0000 \\
\hline 8 & $* * *$ & $* * *$ & & - & 0.7864 & 0.0639 & 0.0000 & 0.0000 & 0.0001 \\
\hline 9 & $* * *$ & $* * *$ & & & - & 0.1436 & 0.0000 & 0.0000 & 0.0000 \\
\hline 12 & $* * *$ & $* * *$ & & & & - & 0.0000 & 0.0000 & 0.0000 \\
\hline 13 & & & $* * *$ & $* * *$ & $* * *$ & $* * *$ & - & 0.0916 & 0.7176 \\
\hline 15 & & & $* * *$ & $* * *$ & $* * *$ & $* * *$ & & - & 0.2210 \\
\hline 17 & & & $* * *$ & $* * *$ & $* * *$ & $* * *$ & & & - \\
\hline
\end{tabular}

There is no pattern among the three sample sets (abscised Rutab, light seeds, dark seeds); no single palm always consistently exhibits a low or a high germination percentage, and no clear trend can be observed when comparing the germination percentage of different seasons for each individual palm (Table 2). Likewise, no linear trend in the germination percentage could be observed along the driveway (Table $2)$, even though there is the low slope from the north (palm $n^{\circ} 17$ ) to the south (palm $n^{\circ} 1$ ) (Figure 4) which may influence the surface water flow during times of extreme rainfall. This lack of trend is supported by observations of seed sizes, which demonstrate a high degree of variability between palms (Table 4).

The southern-most palm at the lowest point of the slope $\left(n^{\circ} 1\right)$ has a lower germination rate among both light and dark seeds than most other palms. Palm $n^{\circ} 3$ also shows a significantly lower germination rate among light seeds (Table 5). Looking at the levels of significance of differences in actual germination percentage for light (Table 5) as well as dark seeds (Table 6), a pattern emerges with two marginal groups (palms $\mathrm{n}^{\circ} 1$ and 3 in the south and palms $\mathrm{n}^{\mathrm{o}} 15$ and 17 in the north) and central group (palms 5, 7, 8,
$9,12)$. As there are no environmental or historic explanations for this pattern, other, most likely genetic factors must be involved. ${ }^{1}$

\section{Alma Park Church}

In the case of Alma Park Church, there are two palm clusters (each planted in a $7 \times 7 \mathrm{~m}$ square), one at the church and one at the hall. Each cluster comprises three females and one male plant, which is, again, a random outcome as all palms, when planted, had been juveniles. There is substantial variability between the individual palms of each cluster and between the palms of the clusters (Table 2) as well as between seasons among the same palm (Table 2), demonstrating no underlying pattern. In the church group, palm 2 has a significantly higher AGP than all other palms of both the church and the hall group, both concerning light and dark seeds (Table 7, Table 8). Palm $\mathrm{n}^{\circ} 2$ is also much larger (and thus older) than the rest (Spennemann 2020a) indicating that it derived from a different plant stock than the others. No significant differences could be observed in the hall group (Table 7, Table 8). 

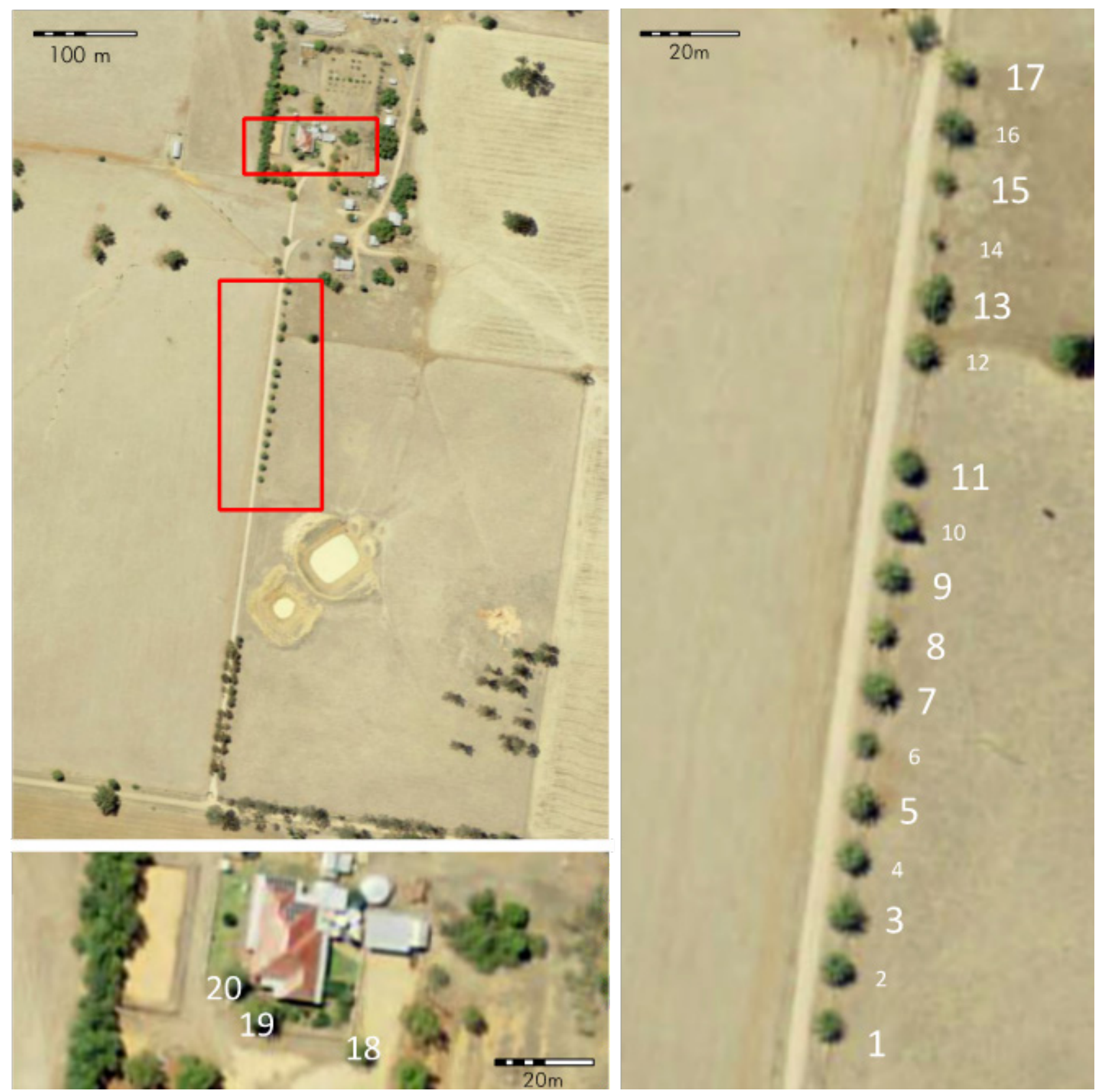

Figure 4. Locations of palms at the property 'Glenalvon', Alma Park. Small numbers denote male palms.

Table 7. Results of the pair-wise chi-square test for comparing germination percentage between seeds of different palms at the Alma Park Church: light seeds, Significance: $* \mathrm{p}<0.05, * * \mathrm{p}<0.005, * * * \mathrm{p}<0.001$

$\begin{array}{llllll}\text { Palm } & 1 & 2 & 3 & 5 & 6 \\ 1 & - & 0.0007 & 0.3711 & 0.0897 & 0.0070 \\ 2 & * * * & - & 0.0510 & 0.0265 & 0.2034 \\ 3 & & & - & 0.7396 & 0.2648 \\ 5 & & * & & - & 0.2269 \\ 6 & * & & & & -\end{array}$

Table 8. Results of the pair-wise chi-square test for comparing germination percentage between seeds of different palms at the Alma Park Church: dark seeds, Significance: * $\mathrm{p}<0.05, * * \mathrm{p}<0.005, * * * \mathrm{p}<0.001$

$\begin{array}{lllllll}\text { Palm } & 1 & 2 & 3 & 5 & 6 & 8 \\ 1 & - & 0.00 & 0.1202 & 0.0232 & 0.7193 & 0.6446 \\ 2 & * * * & - & 0.0000 & 0.0114 & 0.0000 & 0.0000 \\ 3 & & * * * & - & 0.2487 & 0.0990 & 0.0317 \\ 5 & * & * & & - & 0.0201 & 0.0069 \\ 6 & & * * * & & & - & 1.0000 \\ 8 & & * * * & * & * & & -\end{array}$




\section{Netherlands, Alma Park}

With their extremely low germination rate $(0.8 \%$, $\mathrm{n}=120$ ) the dark seeds of the southern palm at the Netherlands homestead are an anomaly, as they are statistically very significantly lower $(p<0.0001)$ than all other samples. This not surprising given that the palms are much older than the others under discussion. Its plant stock would have been sourced independently from the others in the vicinity. Both palms at 'Netherlands' are female and thus would have been fertilised by pollen from palms $n^{\circ} 4$ or $n^{\circ} 7$ at Alma Park Church. Both palms show significant differences in germination between seasons (northern palm $p$ $=0.0377$, southern palm $p<0.0001)$ as well as between each other in the same season (light seeds $p$ $<0.0001$; dark seeds $p=0.0011$ ).

\section{Discussion}

The study set out to investigate whether there were inter-annual differences in the germination potential of old vs fresh Phoenix canariensis seeds among individual palms and whether there are differences in the germination percentage and germination rates (speed) of seed between individual palms of the same year.

While it was known that $P$. canariensis seeds are comparatively tolerant to desiccation (Batista et al. 2016; Dickie \& Pritchard 2002), it was expected that $P$. canariensis seeds would follow the pattern of seed other plants which tend to exhibit a decreasing fitness to germinate as time passes. The experiment has clearly shown that this is not the case. No statistically significant differences in germination rates could be observed (at five weeks) in $87.9 \%$ of all sample pairings irrespective of seed type and treatment involved. Not only that, in $47.4 \%$ of all pairings the germination rate was statistically indistinguishable at $p<0.05$. In other words, fresh seeds (both picked off the palm and abscised), dry seeds, and previous seasons' seeds had the same success in germinating. This has implications on the invasiveness of $P$. canariensis palms as the seed bank, which accumulated underneath the canopy during low rainfall seasons, will conceivably lead to an amplified recruitment pulse once environmental conditions improve. Whereas recruitment underneath an existing palm canopy is less of a concern in most settings, this is not the case for palms in floodplain settings. Here, seeds will be dislocated and transported during inundation events, leading to recruitment pulses (Spennemann 2020d).
A case study of $P$. canariensis invasive to a riverine forest in Hay (NSW) noted that, despite a wholesale removal of all juvenile and well as all seeding/ pollinating mature plants, recruitment seemed to have been rapid, facilitated by seed dispersal by Currawongs (Strepera graculina) with flood pulses aiding establishment (Spennemann 2020d). In the light of the present study, older seeds from the seed bank may likely have also contributed.

The overall germination success of a palm can be measured by the number of seedlings that survive to the juvenile stage after which survival is essentially assured unless catastrophic events (bushfires, prolonged flooding) intervene. In this study we were not concerned with the post-germination effects of moisture, frost, and grazing by herbivores that limit the survival of a seedling (Spennemann 2020d). Germination success can be assessed in terms of the actual germination percentage as well as the relative germination percentage. The latter is of significance as germinated seeds with an exposed cotyledonary petiole are prone to predation by rodents and insects.

Quick germination is advantageous in a predator environment. Seed predating beetles, such as Coccotrypes dactyliperda, will tunnel into a seed, establish a brood chamber, and will commence oviposition within 3-5 days after commencement of tunnelling (Spennemann 2019a). The larvae will consume the albumen of the seed, reducing the energy available to the emerging cotyledonary petiole and plumule. Also, if germination is delayed, the larvae will eat out the albumen next to the embryo and thus prevent germination altogether.

In a seed-predating environment, with the presence of Coccotrypes dactyliperda, survival of non-germinated seeds is low. Bar-Shalom and Mendel (2001) could show that $95 \%$ of the seeds that had remained on the ground showed evidence of infestation in the year after abscission. The high germination rate of older seeds is advantageous in a predator environment, as older seeds with their lower moisture content are less likely to be consumed by rodents and are also less likely infested by seed predating beetles than fresh seeds (Spennemann 2018b).

\section{Implications on invasiveness and further research}

The study has shown that while Phoenix canariensis seeds exhibit low inter-seasonal variations in germination potential, high inter-specimen variation does occur. That high variability is caused by the ge- 
netic diversity inherent in a given palm population, as well as environmental factors. At the present stage it is impossible to separate these two factors.

It is desirable to carry out a controlled multi-factorial experiment, whereby infructescences of three female Canary Island date palms are artificially pollinated by three different pollen sources. To examine whether seasonal effects play a role, each $3 \times 3$ combination should be applied to three successively flowering bunches per palm. Ideally, the experiment should be repeated for at least three years to account for any inter-seasonal variations caused by fluctuating environmental conditions.

From an ecological perspective, this pilot study has shown that older, past season seeds remain viable and can germinate successfully if moisture conditions become favourable. In the case of spatially widely dispersed seeds, this allows for a delayed expansion and colonisation (sensu Spennemann 2020e). The extent of this, however, has not yet been fully examined or quantified. To provide data on seed viability over time, a controlled ten-year experiment should be executed, where three complete bunches of a single palm are harvested in their entirety, the seeds extracted, and for each bunch, randomly split into two sets of ten cohorts of 30 seeds each. These are to be stored, one set at a stable room temperature and one set exposed to the elements (but safe from seed predators), with one cohort (both storages option, three source bunches) germinated annually.

\section{Authors Contribution}

Conceptualization: DHRS; Methodology: DHRS; Sample Collection: DHRS, MP; Data entry: MP; Formal analysis: DHRS, WR; Writing - original draft preparation: DHRS; Writing - review and editing: DHRS, MP, WR; Visualization: DHRS.

\section{ACKNOWLEDGMENTS}

We are indebted to Robert Cook and Kylie Kent (both Southern Area Technical Support Faculty of Science, Charles Sturt University) for assistance with the germination experiments. Marika Andronikos (Albury), Gavin Kotzur ('Pinevilla', Alma Park), and Dale Lieschke ('Glenalvon,' Alma Park) kindly permitted access to the palms on their property and the collection of samples.

\section{Notes}

1. Studies of the commercial date palm (Phoenix dactylifera), a congener of $P$. canariensis, have demonstrated the role of pollen sources on the physical characteristics of drupes and seeds (dimensions, weights) and the chemical characteristics of drupes (fruit sugars, phenolics) (Ghanim \& Muhtaseb, 2006; Hafez et al., 2014; Haffar et al., 1997; Merwad et al., 2015; Rezazadeh et al., 2013; Salomon-Torres et al., 2017; Shafique et al., 2011). As $P$. dactylifera freely hybridises with $P$. canariensis, these observations can be ported cum grano salis to that species (André, 1888; González-Pérez \& Sosa, 2009). At Glenalvon the potential genetic situation is complex. Pollination from an external source can be excluded. Given that there are ten female and seven male plants at the driveway of the Glenalvon property, 70 pairings are possible which can result in 210 different Mendelian combinations in any given year. Assuming pollen production among the male palms is equal, not all palms have an even chance of being fertilised by a male, as the distance to the pollen source is likely to influence the outcome with the closest pollen provider having the greatest chance of fertilisation. This has not been modelled for this paper.

\section{REFERENCES}

Ahmed, I. A., Ahmed, A. W. K., \& Robinson, R. K. (1995) Chemical composition of date varieties influenced by the stage of ripening. Food Chemistry, 54, 305-309. DOI: https://doi.org/10.1016/0308-8146(95)00051-J

Al-Wasel, A., \& Warrag, M. (1998) Effect of fruit developmental stage, seed scarification and operculum removal on seed germination of date palm. Agricola Science, 10, 153-161.

Aljuburi, H. J., Al-Masry, H., \& Al-Muhanna, S. A. (2000) 479 Fruit Characteristics and Productivity of Date Palm Trees (Phoenix dactylifera L.) as Affected by Some Growth Regulators. Hortscience, 35(3), 476E-477. DOI: https://doi.org/10.21273/HORTSCI.35.3.476E

Amira, E. A., Guido, F., Saafi, E. B., Issaoui, M., Nesrine, Z., Ferchichi, A., et al. (2011) Chemical and aroma volatile compositions of date palm (Phoenix dactylifera L.) fruits at three maturation stages. Food Chemistry, 127(4), 1744-1754. DOI: https://doi. org/10.1016/j.foodchem.2011.02.051

André, E. (1888) Un nouveaux Phoenix hybride. Revue Horticole, 60(3), 366. 
Azad, M. S., Rahman, M. T., \& Matin, M. A. (2011) Seed germination techniques of Phoenix dactylifera: A new experience from Bangladesh. Frontiers of Agriculture in China, 5(2), 241-246. DOI: https:/doi.org/10.1007/ s11703-011-1086-2

Baliga, M. S., Baliga, B. R. V., Kandathil, S. M., Bhat, H. P., \& Vayalil, P. K. (2011) A review of the chemistry and pharmacology of the date fruits (Phoenix dactylifera L.). Food Research International, 44(7), 1812-1822. DOI: https://doi.org/10.1016/j.foodres.2010.07.004

Bar-Shalom, O., \& Mendel, Z. (2001) Seasonal changes in the seed bank in date palm (Phoenix dactylifera) orchards and the involvement of the date-stone beetle (Coccotrypes dactyliperda). Phytoparasitica, 29(1), 84-85.

Barrow, S. C. (1998) A monograph of Phoenix L. (Palmae: Coryphoideae). Kew Bulletin, 53(3), 513-575.

Baskin, J. M., \& Baskin, C. C. (2014) What kind of seed dormancy might palms have? Seed Science Research, 24, 17-22. DOI: https://doi.org/10.1017/ $\underline{\mathrm{S} 0960258513000342}$

Batista, G. S., Mazzini-Guedes, R. B., Pivetta, K. F. L., Pritchard, H. W., \& Marks, T. (2016) Seed desiccation and salinity tolerance of palm species' Carpentaria acuminata, Dypsis decaryi, Phoenix canariensis, and Ptychosperma elegans. Australian Journal of Crop Science, 11(12), 1630. DOI: https://doi.org/10.21475/ ajcs.2016.10.12.PNE204

Beech, E. (2017) Phoenix canariensis, Palma Canaria. The IUCN Red List of Threatened Species 2017. DOI: https://doi.org/10.2305_IUCN.UK.2017-3.RLTS. T13416997A13417001.en.pdf

Biradar, N., \& Mahabale, T. (1969). Studies on palms: Fruits, seeds and seed germination in the genus Phoenix L. Proceedings of the Indian Academy of Sciences-Section B, 70(2), 55-65. DOI: https://doi. org/10.1007/BF03052076

Borzì, A. (1912) Sulla coltura del Dattero come Pianta da frutta in Sicilia. Bollettino dell R. Orto Botanico e Giardino Coloniale di Palermo, 9(1-3), 40-60. , 9(1-3), 40-60.

Broschat, T. K., \& Donselman, H. (1989) Palm seed storage and germination studies. Principes, 32(1), 3-12.

Chatty, Y., \& Tissaoui, T. (1999). Effect of Temperature on Germination of Ornamental Palm Trees in Tunisia. In: II International Symposium on Ornamental Palms \& other Monocots from the Tropics. Acta Horticulturae, 486, 165-167. DOI: https://doi.org/10.17660/ActaHortic.1999.486.22
Cohen, Y., Slavkovic, F., Birger, D., Greenberg, A., Sadowsky, A., Ish-Shalom, M., . . . Kamenetsky, R. (2014). Fertilization and fruit setting in date palm: biological and technological challenges. In: XXIX International Horticultural Congress on Horticulture: Sustaining Lives, Livelihoods and Landscapes. Acta Horticulturae, 1130, 351-358. DOI: https://doi. org/10.17660/ActaHortic.2016.1130.53

Di Tomaso, J. M., \& Healy, E. A. (2006) Weeds of California and other western states. Oakland, CA: University of California, Division of Agriculture and Natural Resources.

Dickie, J. B., \& Pritchard, H. W. (2002). Systematic and evolutionary aspects of desiccation tolerance in seeds. In M. Black \& H. W. Pritchard (Eds.), Desiccation and survival in plants: drying without dying (pp. 239259). Wallingford: CAB International.

Djibril, S., Mohamed, O. K., Diaga, D., Diégane, D., Abaye, B., Maurice, S., \& Alain, B. (2005) Growth and development of date palm (Phoenix dactylifera L.) seedlings under drought and salinity stresses. African Journal of Biotechnology, 4(9), 968-972.

Djouab, A., Benamara, S., Gougam, H., Amellal, H., \& Hidous, K. (2016) Physical and antioxidant properties of two Algerian date fruit species (Phoenix dactylifera L. and Phoenix canariensis L.). Emirates Journal of Food and Agriculture, 28(9), 601-608. DOI: https:// doi.org/10.9755/ejfa.2015-12-1056

Donselman, H. (1982) Palm Seed Germination Studies. Proceedings of the Florida State Horticultural Society, 95, 256-257.

El Arem, A., Saafi, E. B., Flamini, G., Issaoui, M., Ferchichi, A., Hammami, M., et al. (2012) Volatile and nonvolatile chemical composition of some date fruits (Phoenix dactylifera L.) harvested at different stages of maturity. International Journal of Food Science \& Technology, 47(3), 549-555. DOI: https://doi. org/10.1111/j.1365-2621.2011.02876.x

El-Tarawy, M. A., Menesy, F. A., \& Nofal, E. M. (1989) Seed germination and seedling growth of Canary Island date palm (Phoenix canariensis Chaub.) as affected by some pregermination treatments. Journal of Agricultural Research, Tanta University, 13, 28-37.

Eltayeb, E. A., Al-Hasni, A. S., \& Farooq, S. A. (1999) Changes in soluble sugar content during the development of fruits in some varieties of Omani date palm (Phoenix dactylifera L.). Pakistan Journal of Biological Sciences, 2, 255-258. DOI: https://doi. org/10.3923/pjbs.1999.255.258 
Gátin, C.-L. (1906) Recherches anatomiques et chimiques sur la germination des palmiers. Annales des Sciences Naturelles, Botanique, 3(4-6), 191-314.

Ghanim, H. D., \& Muhtaseb, J. A. A. (2006) Effect of Pollen Source on Yield, Quality and Maturity of 'Mejhool' Date Palm. Jordan Journal of Agricultural Sciences, 2(1), 8-15.

González-Pérez, M. A., \& Sosa, P. A. (2009) Hybridization and introgression between the endemic Phoenix canariensis and the introduced $P$. dactylifera in the Canary Islands. Open Forest Science Journal, 2, 78-85. DOI: https://doi.org/10.2174/1874398600902010078

Hafez, O. M., Saleh, M. A., Mostafa, E., Naguib, M., \& Ashour, N. (2014) Effect of pollen grain sources on yield and fruit quality of Samany date palm. International Journal of Agricultural Research, 9(8), 164168. DOI: https://doi.org/10.3923/ijar.2014.164.168

Haffar, I., Al Juburi, H., \& Ahmed, M. (1997) Effect of Pollination Frequency and Pollen Concentration on Yield and Fruit Characteristics of Mechanically Pollinated Date Palm Trees (Phoenix dactylifera var. Khalas). Journal of Agricultural Engineering Research, 68(1), 11-14. DOI: https://doi.org/10.1006/jaer.1997.0171

Jenhani, W. (1992). Ecological and genetic study of Phoenix theophrasti and Phoenix canariensis in Crete. Chania (Crete): Mediterranean Agronomic Institute of Chania.

Lipnitz, D., \& Kretschmar, M. (1994) Standortökologische Untersuchungen an Phoenix canariensis hort. ex Chabaud (Arecaceae) auf Gran Canaria und Teneriffa (Kanarische Inseln). Palmarum Hortus Francofortensis: Palmengarten wissenschaftliche Berichte, 4, 23-63.

Maguire, J. D. (1962) Speed of germination aid in selection and evaluation for seedling emergence and vigor. Crop Science, 2, 176-177. DOI: https://doi. org/10.2135/cropsci1962.0011183X000200020033x

Marcus, J., \& Banks, K. (1999) A Practical Guide to Germinating Palm Seeds. Principes, 43(2), 56-59.

Martfn Alemán, N., Leon Hernández, A. M. d., \& Rodríguez Perez, J. A. (1999). Effect of Salinity on Germination of Phoenix Canariensis and Sabal Palmetto (Arecaceae). In: II International Symposium on Ornamental Palms \& other Monocots from the Tropics. Acta Horticluturae, 486, 209-213. DOI: https://doi. org/:10.17660/ActaHortic.1999.486.30

Martín-Sánchez, A. M., Cherif, S., Vilella-Esplá, J., Ben-Abda, J., Kuri, V., Pérez-Álvarez, J. Á., \& Sayas-Barberá, E. (2014) Characterization of novel intermediate food products from Spanish date palm (Phoenix dactylifera L., cv. Confitera) co-products for industrial use. Food Chemistry, 154, 269-275. DOI: https://doi.org/10.1016/j.foodchem.2013.12.042

Meerow, A. W., \& Broschat, T. K. (2017). Palm Seed Germination (Vol. BUL274). Miami: Environmental Horticulture Department UF/IFAS Extension.

Merwad, M., Mostafa, E., Saleh, M., \& Mansour, A. (2015) Yield and fruit quality of Hayany date palm as affected by different pollen grain sources. International Journal of ChemTech Research, 8(6), 544-549. DOI: https://doi.org/10.21608/ejoh.2015.1303

Meyer, J.-Y., Lavergne, C., \& Hodel, D. R. (2008) Time Bombs in Gardens: Invasive Ornamental Palms in Tropical Islands, with Emphasis on French Polynesia (Pacific Ocean) and the Mascarenes (Indian Ocean). Palms, 52(2), 71-83.

Mifsud, S. (1996) Germinating Palm Seeds. Chamaerops, 23, 9-22.

Noto, G., \& Romano, D. (1987). Palms in the Urban Environment in the Southern Latitudes of Italy. Acta Horticulturae, 195, 91-97. DOI: https://doi.org/10.17660/ ActaHortic.1987.195.10

Núñez, D. R. (1997) Frutos secos, oleaginosos, frutales de hueso, almendros y frutales de pepita. Murcia: Editum, Universidad de Murcia.

Odetola, J. A. (1987) Studies on seed dormancy, viability, and germination in ornamental palms. Principes, 31, 24-30.

Pacheco, M. A. (2001) Effects of flooding and herbivores on variation in recruitment of palms between habitats. Journal of Ecology, 89(3), 358-366. DOI: https://doi. org/10.1046/j.1365-2745.2001.00548.x

Pammenter, N., \& Berjak, P. (2000) Evolutionary and ecological aspects of recalcitrant seed biology. Seed Science Research, 10(3), 301-306. DOI: https://doi. org/10.1017/S0960258500000349

Pimenta, R. S., da Luz, P. B., Pivetta, K. F. L., de Castro, A., \& Pizetta, P. U. C. (2010) Efeito da maturação e temperatura na germinação de sementes de Phoenix canariensis hort. ex Chabaud - Arecaceae. Revista Árvore, 34(1), 31-38. DOI: https://doi.org/10.1590/ S0100-67622010000100004

Pritchard, H. W., Wood, C. B., Hodges, S., \& Vautier, H. J. (2004) 100-seed test for desiccation tolerance and germination: a case study on eight tropical palm species. Seed Science and Technology, 32(2), 393-403. DOI: https://doi.org/10.15258/ sst.2004.32.2.11

Rezazadeh, R., Hassanzadeh, H., Hosseini, Y., Karami, Y., \& Williams, R. R. (2013) Influence of pollen source on fruit production of date palm (Phoenix dactylifera L.) cv. Barhi in humid coastal regions of southern Iran. Scientia Horticulturae, 160, 182-188. DOI: https://doi.org/10.1016/j.scienta.2013.05.038 
Robinson, M. L. (2009). Cooperative Extension SP-02-09: Cultivated Palm Seed Germination. Reno: University of Nevada.

Rubio Neto, A., Silva, F. G., Sales, J. d. F., Reis, E. F. d., Silva, M. V. V. d., \& Souza, A. L. (2012) Effect of drying and soaking fruits and seeds on germination of macaw palm (Acrocomia aculeata [Jacq.] Loddiges ex MART.). Acta Scientiarum. Agronomy, 34(2), 179-185. DOI: https://doi.org/10.4025/actasciagron. v34i2.11752

Salomon-Torres, R., Ortiz-Uribe, N., Villa-Angulo, R., Villa-Angulo, C., Norzagaray-Plasencia, S., \& García-Verdugo, C. D. (2017) Effect of pollenizers on production and fruit characteristics of date palm (Phoenix dactylifera L.) cultivar Medjool in Mexico. Turkish Journal of Agriculture and Forestry, 41, 338347. DOI: https://doi.org/10.3906/tar-1704-14

Saro, I., Robledo-Arnuncio, J. J., González-Pérez, M. A., \& Sosa, P. A. (2014) Patterns of pollen dispersal in a small population of the Canarian endemic palm (Phoenix canariensis). Heredity, 113(3), 215-223. DOI: https://doi.org/10.1038/hdy.2014.16

SAS Institute. (2015) SAS/STAT® 14.1 User's Guide. Cary, NC: SAS Institute Inc.

Scheffé, H. (1953) A Method for Judging All Contrasts in the Analysis of Variance. Biometrika, 40, 87-104. DOI: https://doi.org/10.1093/biomet/40.1-2.87

Shafique, M., Khan, A. S., Malik, A. U., Shahid, M., Rajwana, I. A., Saleem, B. A., et al. (2011) Influence of pollen source and pollination frequency on fruit drop, yield and quality of date palm (Phoenix dactylifera L.) cv. Dhakki. Pakistan Journal of Botany, 43(2), 831-839.

Singh, R. S., \& Bhargava, R. (2009) Effect Of Seed Treatments on Germination and Growth Behaviour in Date Palm (Phoenix Species) under hot arid Conditions. Journal of Tropical Forestry, 25(1-2), 42-48.

Sosa, P. A., Naranjo, A., Márquez, M., Gil, J., \& Saro, I. (2016). Mapping of palm trees and palm groves (Phoenix canariensis) from the Canary Islands: Distribution and census. In: EUNOPS XVI. International Meeting of the European Network of Palm Scientists, 7 - 9 May 2016, Las Palmas de Gran Canaria.

Spanner, T. W. (2018). Phoenix canariensis. Canary Island Date Palm. Retrieved from https://www.rarepalmseeds.com/pix/PhoCan.shtml (Accessed 13 June 2018)

Spennemann, D. H. R. (2018a) Canary Islands Palms (Phoenix canariensis) in Australia: introduction and early dispersal. Palms, 62(4), 185-201.

Spennemann, D. H. R. (2018b). An Experimental Evalu- ation of Food Preferences and Associated Hatching Times of the Date Stone Beetle, Coccotrypes dactyliperda (Scolytinae, Coleoptera). Institute for Land, Water and Society Report, no 120. Albury, NSW: Institute for Land, Water and Society, Charles Sturt University.

Spennemann, D. H. R. (2018c). Geographical distribution of four key ornamental and production palm species Phoenix canariensis, $P$. dactylifera, Washingtonia filifera and W. robusta. Albury, NSW: Institute for Land, Water and Society, Charles Sturt University. DOI: https://doi.org/10.13140/RG.2.2.22524.16004

Spennemann, D. H. R. (2018d). Phoenix canariensis seed encountered in scats and ejecta collected at Alma Park. Albury, NSW: Institute for Land, Water and Society, Charles Sturt University. DOI: https://doi. org/10.13140/RG.2.2.36365.36329

Spennemann, D. H. R. (2019a) Biology, ecology and distribution of the date stone beetle, Coccotrypes dactyliperda (Scolytinae, Coleoptera). Zoology in the Middle East, 65(2), 163-182. DOI: https://doi.org/10.108 $\underline{0 / 09397140.2019 .1571743}$

Spennemann, D. H. R. (2019b) Canary Islands Palms (Phoenix canariensis) as ornamental plants. The first thirty years of the horticultural trade. Huntia, 17(2), 79-102.

Spennemann, D. H. R. (2019c) The connective potential of vertebrate vectors responsible for the dispersal of the Canary Island date palm (Phoenix canariensis). Flora, 259, 151468. DOI: https://doi.org/10.1016/j. flora.2019.151468

Spennemann, D. H. R. (2019d). Phoenix canariensis and Washingtonia robusta drupes consumed by the Pied Currawong (Strepera graculina). A photographic documentation. Albury, NSW: Institute for Land, Water and Society, Charles Sturt University.

Spennemann, D. H. R. (2020a). Background to the Palms at Alma Park (NSW) I: Alma Park Lutheran Church. Albury, NSW: Institute for Land, Water and Society, Charles Sturt University. DOI: https://doi. org/10.13140/RG.2.2.22160.84481

Spennemann, D. H. R. (2020b). Background to the Palms at Alma Park (NSW) II: Netherlands Homestead. Albury, NSW: Institute for Land, Water and Society, Charles Sturt University. DOI: https://doi. org/10.13140/RG.2.2.32227.17444

Spennemann, D. H. R. (2020c). Background to the Palms at Alma Park (NSW) III: Glenalvon Homestead. Albury, NSW: Institute for Land, Water and Society, Charles Sturt University. DOI: https://doi. org/10.13140/RG.2.2.28871.73127 
Spennemann, D. H. R. (2020d) Canary Island date palms invading a remnant riverine eucalypt forest in south-eastern Australia: processes and patterns of recruitment. Cunninghamia, 20, 245-257. DOI: https:// doi.org/10.7751/cunninghamia.2020.20.013

Spennemann, D. H. R. (2020e) Frugivory and seed dispersal revisited: codifying the plant-centred net benefit of animal-mediated interactions. Flora, 263, 151534. DOI: https://doi.org/10.1016/j.flora.2019.151534

Spennemann, D. H. R. (2020f) The role of canids in the dispersal of commercial and ornamental palm species. Mammal Research, 66, 57-74. DOI: https://doi. org/10.1007/s13364-020-00535-6

Spennemann, D. H. R., Kent, K., \& Cook, R. (2018). Uninvited guests: Mass Emergence of Scolytinid Beetles in a Seed Germination Experiment and its Management. Institute for Land, Water and Society Report, $\mathrm{n}^{\circ}$ 118. Albury, NSW: Institute for Land, Water and Society, Charles Sturt University.

Spennemann, D. H. R., \& Pike, M. (2019) Rites of Passage: germination of regurgitated and defecated Phoenix canariensis seeds. Proceedings of the Linnean Society of New South Wales, 141, 49-59.

Staples, G. W., Herbst, D., \& Imada, C. T. (2000) Survey of invasive or potentially invasive cultivated plants in Hawai'i. Bishop Museum Occasional Papers, 65, $1-35$.

Sumianah, G. M., Makki, Y. M., \& Rumney, T. G. (1984) Changes in the chemical composition of three cultivars of date seed during germination. Date Palm Journal, 3(2), 395-407.

Williams, P. A. (2008). Biological success and weediness of some terrestrial weeds not presently in the Northland Regional Council's RPMS. Prepared for: Northland Regional Council. Nelson: Land Care Research.

Wotherspoon, S. H., \& Wotherspoon, J. A. (2002). The evolution and execution of a plan for invasive weed eradication and control, Rangitoto Island, Hauraki Gulf, New Zealand. In C. R. Veitch \& M. N. Clout (Eds.), Turning the tide: the eradication of invasive species. Proceedings of the International Conference on Eradication of Island Invasives (pp. 381-388). Cambridge: IUCN.

Zona, S. (2008) The horticultural history of the Canary Island Date Palm (Phoenix canariensis). Garden History, 36, 301-308. DOI: https://doi.org/10.2307/40649462 